\title{
Nutrient Digestibility and Performances of Frisian Holstein Calves Fed with Pennisetum purpureum and Inoculated with Buffalo's Rumen Bacteria
}

\author{
I. Prihantoro ${ }^{\mathrm{a}, *}$, D. Evvyernie ${ }^{\mathrm{a}}$, Suryani ${ }^{\mathrm{b}}$, L. Abdullah ${ }^{\mathrm{a}}$, \& T. Toharmat ${ }^{\mathrm{a}}$ \\ ${ }^{a}$ Department of Nutrition and Feed Technology, Faculty of Animal Science, Bogor Agricultural University \\ ${ }^{b}$ Department of Biochemistry, Faculty of Mathematics and Natural Sciences, Bogor Agricultural University \\ Jln. Agatis, Kampus IPB Darmaga, Bogor 16680 \\ (Received 27-01-2014; Reviewed 18-02-2014; Accepted 23-06-2014)
}

\begin{abstract}
Buffalo's rumen bacteria (BRB) are potential in digesting fiber feed. BRB already adapted well with low quality forages and agricultural byproducts. The aim of this study was to determine the effect of buffalo's rumen bacteria (BRB) consortium inoculated into preweaning Frisian Holstein calves on nutrient digestibility, physiological status, mineral uptake, and blood profile. This study used 14 isolates of bacteria isolated from rumen fluid of four local buffalos. The research units consisted of seven Frisian Holstein calves at two weeks old with the average body weight of $43.6 \pm 4.5 \mathrm{~kg}$. Calves were inoculated with $20 \mathrm{~mL}$ of buffalo's rumen bacteria isolates $\left[4.56 \times 10^{9} \mathrm{cfu} / \mathrm{mL}\right]$ every morning for 10 weeks. The calves were divided into two groups i.e., three calves received bacterial inoculation and four calves without any inoculation. The variables which were analyzed in the preweaning and weaning period were feed intake, digestibility, average daily gain (ADG), feed conversion ratio (FCR), rumen fermentation characteristics, body weight, physiological status, blood profile, and mineral status. Data were analyzed statistically using t-test. The results showed that inoculation of buffalo's rumen bacteria into Frisian Holstein calves effectively increased feed intake, characteristics of leukocytes and neutrophils, and cobalt (Co) uptake during the weaning period. Inoculation of rumen bacteria improved rumen $\mathrm{pH}$ during preweaning and weaning periods. Inoculation of rumen bacteria also had no negative effects on digestibility, feed conversion (FCR), average daily gain (ADG), and physiological status.
\end{abstract}

Key words: buffalo rumen bacteria, digestibility, physiological status, blood profile, Pennisetum purpureum

\section{ABSTRAK}

Bakteri rumen kerbau (BRK) merupakan bakteri yang mempunyai potensi tinggi dalam pemanfaatan pakan sumber serat. Bakteri ini telah teradaptasi dengan baik terhadap pakan hijauan dan limbah pertanian yang berkualitas rendah. Inokulasi bakteri rumen kerbau pada pedet memungkinkan rumen berkembang lebih awal dan fermentasi di dalam rumen lebih optimal. Penelitian ini bertujuan untuk mengetahui efektivitas inokulasi bakteri asal rumen kerbau pada pedet Frisian pada kecernaan pakan, status fisiologis, serapan mineral, dan profil darah. Penelitian ini menggunakan 14 isolat bakteri yang berasal dari cairan rumen empat jenis kerbau lokal. Penelitian terdiri atas tujuh ekor pedet prasapih jenis Frisian Holstein berumur dua minggu dengan rataan bobot badan $43,6 \pm 4,5 \mathrm{~kg}$. Rumen pedet diinokulasi $20 \mathrm{~mL}$ konsorsium bakteri dalam bentuk dadih setiap pagi hari selama 10 minggu dengan cara dicekok menggunakan spoit pada konsentrasi bakteri $4,56 \times 10^{9} \mathrm{cfu} / \mathrm{mL}$. Tiga ekor pedet diberi inokulan bakteri dan empat ekor sebagai kontrol. Peubah yang dianalisis pada penelitian periode prasapih dan pascasapih antara lain konsumsi pakan, kecernaan, pertambahan bobot badan, konversi pakan, karakteristik fermentasi, bobot badan, status fisiologi, profil darah, dan status mineral. Data dianalisis menggunakan uji-t. Hasil penelitian menunjukkan bahwa inokulasi bakteri rumen kerbau signifikan meningkatkan konsumsi pakan, jumlah leukosit dan neutrofil, serapan cobalt pada pedet umur 12 minggu. Inokulasi bakteri memperbaiki $\mathrm{pH}$ rumen selama penelitian dan tidak memberikan pengaruh negatif pada kecernaan, konversi pakan (FCR), pertambahan bobot badan harian (PBBH), dan status fisiologi pedet.

Kata kunci: bakteri rumen kerbau (BRK), kecernaan, status fisiologis, profil darah, Pennisetum purpureum

*Corresponding author:

E-mail: iprihantoro@yahoo.com 


\section{INTRODUCTION}

Problem on the calves rearing program is the slow adaptation of calves to solid and fibrous feeds which causes a slow weaning process. This slow adaptation is related to the undeveloped calf rumen and rumen microorganisms. The main factor affecting the development of rumen, reticulum and omasum is the type of feed given. Grain and forage can stimulate the development of reticulo-rumen. Specific factors that stimulate the development of rumen epithelial are propionate and butyrate (Davis \& Drackley, 1998). The presence of rumen microbes in ruminant has an important role in digesting low quality of feed (Sutardi, 1980). The major fiber digesting bacteria are rumen bacteria that have important roles in digesting fiber feed by increasing the solubility of crystalline cellulose (Shinkai \& Kobayashi, 2007). Fiber-digesting bacteria belong to the groups of Fibrobacter succinogenes, Ruminococcus flavefaciens and Ruminococcus albus (Sawanon \& Kobayashi, 2006; Kumar \& Sirohi, 2013).

Fibrous feed is the main energy source for ruminant and has an important role in the development of calf digestive organs (Castell et al., 2013). During digesting the forage, fiber-digesting bacteria will interact synergistically with non-cellulolytic bacteria (Sawanon \& Kobayashi, 2006) by breaking the bonds of methoxyl lignocellulose structures and increase the hydroxyl and carboxyl phenolic (Wahyudi et al., 2010). Some microorganisms, including anaerobic bacteria producing cellulose enzymes, can degrade lignin in the cell walls (Asmare, 2014).

Few studies have looked into the effect of inoculated bacteria into the calf rumen. Inoculated bacteria potentially increased rumen development and fermentation. Inoculated bacteria in preweaning period (4 wk) increased total rumen bacteria and feed intake in fourteen weeks old calves (Prihantoro et al., 2012) and also increased feed intake, feed conversion (Frizzo et al., 2010), and body weight at the age of 3 mo (Dezfouli et al., 2007).

Study about the effect of rumen bacteria of buffalo as probiotic on mineral absorption and blood profile in calves was limited. Lee \& Salminen (2009) reported that probiotic increased mineral absorption in animals. Probiotic can increase cobalt (Co) uptake on calves at 14 wk of age (Prihantoro et al., 2012). Kinal et al. (2007) suggested that yeast cells also improved the digestibility and absorption of minerals such as phosphorus, magnesium, calcium, copper, potassium, zinc, and manganese. Study about the effect of probiotic on hematology was reported in mice and result showed that probiotic increased hematological parameters and lipid profile (Salahudin et al., 2013).

Buffalo's rumen bacteria consist of Succiniclasticum ruminis, Acetovibrio cellulolyticus, Streptococcus sp, Ruminococcus callidus, Prevotella ruminicola, Bacteroides fragilis, Treponema sp (Pandya et al., 2010). The ability of buffalo's rumen bacteria in increasing nutritional status, physiological parameters, mineral uptake, and hematological profile in calves during preweaning growth period need to be reviewed. The aim of this study was to determine the effectiveness of buffalo's rumen bacteria inoculated into preweaning Frisian Holstein calves fed with Pennisetum purpureum as a fiber source on nutrient digestibility, performance, physiological status, mineral uptake, and blood profile.

\section{MATERIALS AND METHODS}

\section{Animals}

Seven Frisian Holstein preweaning calves at two weeks of age with average body weight of $43.6 \pm 4.5 \mathrm{~kg}$ were used. Calves were housed in individual cages with a size of $2.0 \times 1.5 \mathrm{~m}$ with dry rice straw as bedding. Three calves $(45.3 \pm 4.2 \mathrm{~kg})$ were given bacteria inoculation and four calves $(41.5 \pm 4.0 \mathrm{~kg})$ were used as control.

\section{Preparation of Buffalo's Rumen Bacteria}

Fourteen isolates of buffalo's rumen bacteria (BRB) were isolated from the rumen fluid of four local buffalos that had the ability to degrade fiber source (Prihantoro et al., 2012). Three kinds of rumen fluids were obtained from buffalos raised in Jonggol, West Java and one was obtained from South Jakarta. A $0.1 \mathrm{~mL}$ of single culture bacteria stock was refreshed on $5 \mathrm{~mL}$ medium consisted of 3.7\% Brain Heart Infusion (BHI); 0.05\% Cystein- $\mathrm{HCl}$; $0.05 \%$ starch; $0.05 \%$ glucose; $0.05 \%$ cellubiosa; $0.05 \%$ hemin; and $0.05 \%$ resazurin and incubated at $39^{\circ} \mathrm{C}$. About $2 \%$ refreshed culture bacteria was inoculated into 250 $\mathrm{mL}$ sterile fresh milk and incubated at room temperature $\left(28-32^{\circ} \mathrm{C}\right)$ for $60 \mathrm{~h}$ until becoming curds (modified from Anandan et al., 1999). The 14 isolated bacteria were homogenized and then were inoculated into the experimental calve.

\section{Inoculation of Buffalo's Rumen Bacteria into Preweaning Calves}

During the study, water and feed were given ad-libitum. Then, all calves were given $4 \mathrm{~L}$ of fresh milk/d until the age of 6 weeks, $3 \mathrm{~L} / \mathrm{d}$ until the age of 7 weeks, and $2 \mathrm{~L} / \mathrm{d}$ until the age of 8 weeks. All calves were weaned after the age of 8 weeks. Inoculation of BRB was done by inserting $20 \mathrm{~mL} / \mathrm{d}$ of BRB $\left(4.56 \times 10^{9} \mathrm{cfu} / \mathrm{mL}\right)$ at $08: 00 \mathrm{~h}$ through the mouth by using plastic syringe. The control calves were without any inoculation. Composition and nutrient content of the ration is presented in Table 1.

\section{Data Collection and Analysis}

Data of room temperature and humidity were recorded every day at 08:00 and 15:00 h. Feed intake and nutrient digestibility were measured for $7 \mathrm{~d}$ at the ages of $8 \mathrm{wk}$ (preweaning) and $12 \mathrm{wk}$ (weaning) by the total collection method. Fermentability of rumen fluid (VFA, $\mathrm{NH}_{3^{\prime}} \mathrm{pH}$, and bacteria) and hematology were also measured. The rumen fluid was withdrawn by using a vacuum pump, whereas blood samples were taken from jugular vein by using syringe. Respiration, heart rate, and rectal temperature were measured every week at 8:00 and $14: 00 \mathrm{~h}$. 
Table 1. The compositions ingredient and nutrients content of ration (dry matter)

\begin{tabular}{lcc}
\hline & $\begin{array}{c}\text { Preweaning } \\
\text { period }\end{array}$ & $\begin{array}{c}\text { Weaning } \\
\text { period }\end{array}$ \\
\hline Ingredients (\% dry matter) & & \\
Corn & 45 & 43 \\
Pollard & 15 & 16 \\
Soybean meal & 30 & 14.5 \\
Molasses & 10 & 10 \\
Pennisetum purpureum & 0 & 16.5 \\
Nutrient content & & \\
Dry matter (\%) & 84.03 & 84.38 \\
Crude protein (\%) & 20.11 & 16.64 \\
Crude fiber (\%) & 4.88 & 9.96 \\
Ether extract (\%) & 3.23 & 1.53 \\
Ash (\%) & 8.66 & 5.02 \\
Nitrogen free extract (\%) & 47.15 & 51.23 \\
NDF (\%) & 40.19 & 66.73 \\
ADF (\%) & 12.83 & 11.64 \\
Minerals & & \\
Ca (\%) & 1.35 & 3.68 \\
Mg (\%) & 0.25 & 0.27 \\
Zn (ppm) & 75.36 & 98.35 \\
Co (ppm) & 2.13 & 2.12 \\
P (\%) & 0.25 & 0.34 \\
\hline
\end{tabular}

Note: Laboratory of Feed Science and Technology, Department of Nutrition and Technology, Faculty of Animal Science, Bogor Agricultural University (2009)

Dry matter and organic matter of feed and feces were analyzed by using the AOAC method (1990). Apparent nutrient digestibility was calculated from the difference between total feed intake and total feces (based on dry matter). Mineral absorption (Ca, P, Mg, $\mathrm{Zn}$, and $\mathrm{Co}$ ) was calculated based on total mineral in consumed feed minus total mineral excreted in feces. The samples of feeds, feces, and blood for mineral measurements were prepared by using the wet ashing method (Lehmann \& Enders, 2012). Concentrations of $\mathrm{Ca}, \mathrm{Mg}, \mathrm{Zn}$, and Co were measured by using atomic absorption spectrophotometer (AAS) (Campbell, 2009) while mineral $\mathrm{P}$ was measured by using a spectrophotometer. Total Volatile Fatty Acids (T-VFA) was measured by the steam distillation method (AOAC, 1990) and $\mathrm{NH}_{3}$ was measured by Conway micro-diffusion method (Conway, 1950). Rumen bacteria were calculated by using the conventional method of total plate count (Goldman \& Green, 2008). Simple correlation analysis and linear regression analysis were used to determine the relationship of dry matter intake with body weight and abdominal circumference.

Rumen fluid was dissolved into McDougal solution in $10^{-12}$. The results of dilution $10^{-7}-10^{-12}$ were put into Hungate tubes containing sterile solid media consisted of 3.7\% BHI; $0.05 \%$ Cystein- $\mathrm{HCl}, 0.05 \%$ starch; $0.05 \%$ glucose; $0.05 \%$ cellubiosa; $0.05 \%$ hemin, $0.05 \%$ resazurin, and $10 \%$ bakto agar. Blood characteristics of the calves were measured based on Lichtman et al. (2006). Data were analyzed statistically by using t-Test method with $\alpha=0.05$.

\section{RESULTS AND DISCUSSION}

\section{Nutritional Status of Calves Inoculated with Buffalo's Rumen Bacteria}

The averages room temperatures during the study were $24.26 \pm 1.40{ }^{\circ} \mathrm{C}$ in the morning and $31.98 \pm 1.14$ ${ }^{\circ} \mathrm{C}$ in the afternoon with a maximum temperature of $33.47 \pm 0.88{ }^{\circ} \mathrm{C}$ and minimum temperature of $23.33 \pm 1.28$ ${ }^{\circ} \mathrm{C}$. The minimum humidity was $49.57 \pm 8.10 \%$ and a maximum humidity was $87.24 \pm 4.48 \%$. These conditions were not in comfort condition. The ideal humidity should be less than $76 \%$. The conditions of thermo neutral zone for dairy calf are $25-26{ }^{\circ} \mathrm{C}$ (Ulvshammar, 2014).

Feed intake and nutrient digestibility in calves inoculated buffalos rumen bacteria are shown in Table 2. There was no difference in dry matter intake between the inoculated calves and control during the preweaning period. Intakes of dry matter, organic matter, crude protein, crude fiber, fat, nitrogen free extract (NFE), and total digestible nutrient (TDN) in inoculated calves during weaning period were significantly higher $(\mathrm{P}<0.01)$ than in control calves. This indicates that the inoculation of BRB can improve nutrient intake by improving rumen activity. Inoculation of bacteria in the calf can increase feed intake (Frizzo et al., 2010). Probiotic supplementation increased feed intake (Desnoyers et al., 2009) because it improved cellulolytic bacteria in the rumen (Wallace \& Newbold, 1993).

Digestibility of dry matter was not significantly different between inoculated calves and control calves. The nutrient digestibility values of both groups were higher than $74 \%$. The high nutrient digestibility in both groups was an indication of normal growth of rumen microbial population that was able to degrade the feed consumed. Davis \& Drackley (1998) revealed that calves were able to consume dry feed at the age of two weeks and Sutardi (1980) suggested that digestibility of the feed was influenced by the quality and type of material fed to the cattle.

Digestibilities of crude fiber in preweaning and weaning calves (Table 2) were not significantly different between the inoculated calves and control calves because the rumens of control calves have evolved. Furthermore, the increase of feed intake at weaning period resulted in the faster retention time and furthermore the decreased digestibility. According to Dias et al. (2011) retention time of digest has a positive correlation with digestibility of the feed. Davis \& Drackley (1998) reported that feed intake of calve at ten weeks old is $2.0-2.5 \mathrm{~kg} \mathrm{DM} / \mathrm{d}$.

Feed conversion ratio (FCR) and average daily gain (ADG) on preweaning and weaning periods of the two groups were not different significantly. Inoculation of bacteria increased average daily gain of calves by $19.47 \%$ in weaning period. Yaqub et al. (2004) reported that addition of Lactobacillus acidophilus had no significant effect on growth performance and health of calves. Buffalo's rumen bacteria relatively improved feed conversion ratio (FCR) by $16.89 \%$ on weaning period. It indicated that feed intake of calves was efficient. Swinney-Floyd et al. (1999) stated that inoculation of strain Propioni bacterium 
Table 2. Feed intake and nutrient digestibility in calves inoculated with buffalo's rumen bacteria

\begin{tabular}{|c|c|c|c|c|}
\hline \multirow{2}{*}{ Parameter } & \multicolumn{2}{|c|}{ Preweaning } & \multicolumn{2}{|c|}{ Weaning } \\
\hline & Inoculated & Control & Inoculated & Control \\
\hline Calf (n) & 3 & 4 & 3 & 4 \\
\hline \multicolumn{5}{|l|}{ Intake $(\mathrm{g} / \mathrm{d})$ : } \\
\hline Dry matter & $960.03 \pm 129.32$ & $738.66 \pm 253.62$ & $1374.19 \pm 12.05^{\mathrm{A}}$ & $1332.00 \pm \quad 6.96^{\mathrm{B}}$ \\
\hline Crude protein & $229.75 \pm 30.95$ & $173.23 \pm 66.84$ & $270.99 \pm 2.38^{\mathrm{A}}$ & $262.67 \pm \quad 1.37^{\mathrm{B}}$ \\
\hline Crude fiber & $55.75 \pm \quad 7.51$ & $42.04 \pm 16.22$ & $162.21 \pm 1.42^{\mathrm{A}}$ & $157.23 \pm \quad 0.82^{\mathrm{B}}$ \\
\hline Fat & $36.90 \pm \quad 4.97$ & $27.82 \pm 10.73$ & $24.92 \pm 0.22^{\mathrm{A}}$ & $24.15 \pm 0.13^{\mathrm{B}}$ \\
\hline NFE & $538.68 \pm 72.56$ & $406.16 \pm 156.70$ & $834.32 \pm 7.32^{\mathrm{A}}$ & $808.70 \pm \quad 4.23^{\mathrm{B}}$ \\
\hline Organic matter & $861.09 \pm 115.99$ & $649.25 \pm 250.49$ & $1292.43 \pm 11.34^{\mathrm{A}}$ & $1252.75 \pm \quad 6.55^{\mathrm{B}}$ \\
\hline TDN & $722.73 \pm 103.06$ & $545.12 \pm 214.68$ & $1055.68 \pm 10.57$ & $1042.49 \pm 13.53$ \\
\hline \multicolumn{5}{|l|}{ Digestibility (\%): } \\
\hline Dry matter & $77.24 \pm \quad 1.24$ & $78.08 \pm \quad 1.73$ & $77.87 \pm 1.00$ & $79.34 \pm \quad 0.83$ \\
\hline Crude protein & $84.48 \pm \quad 5.14$ & $81.66 \pm \quad 2.51$ & $77.80 \pm 1.31^{\mathrm{B}}$ & $80.11 \pm 1.04^{\mathrm{A}}$ \\
\hline Crude fiber & $18.23 \pm \quad 4.30$ & $21.70 \pm \quad 6.01$ & $44.41 \pm 1.97$ & $43.33 \pm \quad 4.93$ \\
\hline Fat & $90.84 \pm \quad 3.89$ & $85.25 \pm 10.98$ & $82.96 \pm 0.89$ & $84.63 \pm \quad 1.59$ \\
\hline NFE & $82.57 \pm \quad 1.47$ & $82.88 \pm \quad 2.80$ & $87.06 \pm 0.61$ & $88.78 \pm \quad 1.37$ \\
\hline Organic matter & $77.61 \pm \quad 0.95$ & $77.85 \pm \quad 1.91$ & $77.92 \pm 0.88$ & $79.55 \pm \quad 1.15$ \\
\hline $\operatorname{ADG}(\mathrm{g} / \mathrm{d})$ & $357.15 \pm 94.49$ & $366.07 \pm 110.56$ & $565.48 \pm 54.55$ & $455.36 \pm 106.65$ \\
\hline FCR & $1.78 \pm \quad 0.35$ & $1.40 \pm \quad 0.43$ & $2.62 \pm 0.19$ & $3.15 \pm \quad 1.06$ \\
\hline
\end{tabular}

Note: Means in the same row with different superscripts differ significantly $(\mathrm{P}<0.01)$. NFE= nitrogen free extract; $\mathrm{FCR}=$ feed conversion ratio $(\mathrm{FCR})$; $\mathrm{ADG}=$ average daily gain.

P-63 and L. acidophilus strain LA53545 on single and mixed conditions of the cattle did not affect FCR.

\section{Rumen Fermentation Characteristics}

Total VFA, $\mathrm{NH}_{3}$, and the number of bacteria in the calves' rumen fluid were not significantly difference between the two groups (Table 3). The average total VFA and the number of bacteria in the calves' rumen fluid were higher in the inoculated calves as compared to control calves. Rumen $\mathrm{pH}$ in the inoculated calves was significantly higher $(\mathrm{P}<0.05)$ than control calf. This indicates that the BRB inoculation can improve rumen conditions (Musa et al., 2009). Khalid et al. (2011) stated that probiotic increased the rumen $\mathrm{pH}$ and improved rumen microbial ecology in calf. The range of rumen $\mathrm{pH}$ of calves $3 \mathrm{~h}$ after feeding is 6-7.3 (Stobo et al., 1966).

\section{Calf Performances}

The feed intake positively correlated to body weight and calf abdominal circumference (Figure 1). It means that the feed intake is significantly $(\mathrm{P}<0.01)$ affected by calf body weight and abdominal circumference. This was due to the calves were on the growth phase. Feed intake will increase with calf age (Davis \& Drackley, 1998) and inoculation of bacteria to the calf can increase feed intake and feed conversion (Frizzo et al., 2010). The slope rate of feed intake, body weight, and daily body weight gains of inoculated calves were lower than control (Table 4). However, the slope regression of the feed intake of inoculated calves increased more rapidly than control, especially during the weaning period. It showed that the addition of BRB had a positive impact on nutrient intake which was presumably due to the improvements of rumen fermentation system, such as rumen $\mathrm{pH}$. The increased rate of abdominal circumference with
A

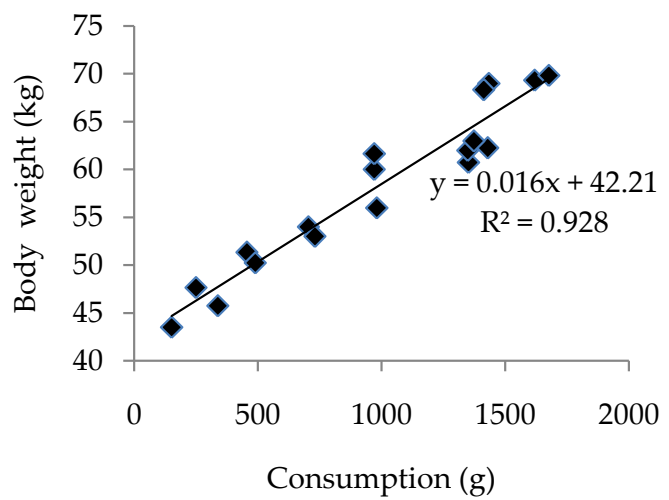

$\mathrm{B}$



Figure 1. The association between dry matter intake and body weight (A), and abdominal circumference (B) of calves 
the increased feed intake showed that the increase in calf weight could be stimulated by increasing feed intake. The growth of the calf could be improved, because the optimum consumption of the calf has not been achieved. The increase in abdominal circumference over consumption also showed the increased activity of the rumen microbes. Calf ration is generally consisted of grain that contains a lot of simple carbohydrate structures that are easily fermented into propionate and butyrate that can stimulate the growth and development of calf's rumen (Suarez et al., 2006).

\section{Physiological Status}

Inoculation of BRB did not affect respiration rate and heart rate in two groups of calves during preweaning and weaning periods (Table 5). It showed that the physiological conditions of the experimental calves were in the normal condition. Davis \& Drackley (1998) reported that respiration rate of calves ranged 22-45 breath/min.

Average rectal temperature in the morning during the preweaning period in the inoculated calves was significantly $(\mathrm{P}<0.05)$ lower than the control (Table 5). This result indicated that the inoculation of BRB improved the status of the calf's body temperature, although both groups were in the normal range. This result was supported by the data that respiration rate of inoculated calves was lower than control. Davis \& Drackley (1998) stated that the normal range of rectal temperature of the calf is $38-39{ }^{\circ} \mathrm{C}$. It showed that inoculation of BRB could change the pattern of rumen fermentation, fermentation products, and body metabolism especially body temperature in the morning.

\section{Blood Profile}

Levels of erythrocytes, hematocrit, and hemoglobin of inoculated calves were similar to those of the control. The values of erythrocytes, hematocrit, and hemoglobin were 7.73-8.45 million $/ \mathrm{mm}^{3}, 29.18 \%-31.66 \%$, and $9.66-10.44 \mathrm{~g} \%$, respectively (Table 6 ). These results indicated that the blood characteristics of both calves groups were in normal physiological conditions. Smith \& Mangkoewidjojo (1988) stated that normal levels of hemoglobin, erythrocyte, and hematocrit are 9-15 g\%, $29 \%-35 \%$, and 4.0-12.0 million $/ \mathrm{mm}^{3}$, respectively.

Leukocytes of inoculated calves during weaning period were significantly higher $(\mathrm{P}<0.01)$ than those of control. The result indicated that inoculation of BRB was able to increase the level of leukocytes. This study showed that level of leukocytes during preweaning and weaning periods were in the normal level. Normal levels of leukocytes were $4.30-14.80$ thousand $/ \mathrm{mm}^{3}$ at 1-4 wk old and 4.91-14.6 thousand $/ \mathrm{mm}^{3}$ at $5-8 \mathrm{wk}$ old (Jezek et al., 2011). Leukocytes are part of immune system that plays a role in regulating the immune system in suppressing pathogen infection (McCowen \& Bistrian, 2003).

The results showed that the differentiation of calf leukocytes in normal range was $16.00 \%-38.25 \%$ for neutrophils, $57.00 \%-78.00 \%$ for lymphocytes, $2.33 \%-4.25 \%$ for monocyte, and $0.5 \%-3.5 \%$ for eosinophils. Smith \& Mangkoewidjojo (1988) stated that the normal range of neutrophils, lymphocytes, monocytes, and eosinophils of calves were $17.5 \%-50 \%, 50 \%-75 \%, 0 \%-6 \%$, and $0 \%-8 \%$, respectively. Neutrophils from inoculated calves during weaning period were significantly higher than control. Phagocytosis provides a first line of defense against in-

Table 3. The characteristics of rumen fermentation of calves inoculated buffalo's rumen bacteria

\begin{tabular}{|c|c|c|c|c|}
\hline \multirow{2}{*}{ Parameter } & \multicolumn{2}{|c|}{ Preweaning } & \multicolumn{2}{|c|}{ Weaning } \\
\hline & Inoculated & Control & Inoculated & Control \\
\hline Calf (n) & 3 & 4 & 3 & 4 \\
\hline T-VFA (mM) & $138.33 \pm 58.38$ & $105.00 \pm 61.91$ & $143.33 \pm 56.86$ & $110.00 \pm 16.32$ \\
\hline $\mathrm{NH}_{3}(\mathrm{mM})$ & $10.03 \pm 1.53$ & $7.53 \pm 2.47$ & $5.68 \pm 1.37$ & $5.66 \pm 2.46$ \\
\hline $\mathrm{pH}$ & $7.20 \pm 0.33^{\mathrm{a}}$ & $6.64 \pm 0.19^{b}$ & $6.97 \pm 0.19^{\mathrm{a}}$ & $6.59 \pm 0.19^{b}$ \\
\hline Bacteria (log cfu/mL) & $13.54 \pm 0.18$ & $13.24 \pm 0.22$ & $13.93 \pm 0.47$ & $13.79 \pm 0.29$ \\
\hline
\end{tabular}

Note: Means in the same row with different superscripts differ significantly $(\mathrm{P}<0.05)$.

Table 4. Regression relationship between feed intake, body weight, and average daily weight of calves

\begin{tabular}{|c|c|c|c|c|c|}
\hline Parameter & Inoculation & \multirow{2}{*}{$\mathrm{R}^{2}$} & Control & \multirow{2}{*}{$\mathrm{R}^{2}$} & \multirow{2}{*}{$P$ value } \\
\hline Calf (n) & 3 & & 4 & & \\
\hline \multicolumn{6}{|l|}{ Feed intake } \\
\hline Preweaning & $Y=241.0 x+7.048$ & 0.996 & $Y=206.5 x+124$ & 0.982 & 0.630 \\
\hline Weaning & $Y=138.3 x+1007$ & 0.626 & $Y=71.69 x+1075$ & 0.412 & 0.105 \\
\hline \multicolumn{6}{|l|}{ Body weight } \\
\hline Preweaning & $Y=3.657 x+40.31$ & 0.986 & $Y=3.014 x+37.78$ & 0.987 & 0.172 \\
\hline Weaning & $Y=0.15 x+68.75$ & 0.094 & $Y=0.65 x+60.37$ & 0.804 & 0.262 \\
\hline \multicolumn{6}{|c|}{ Average daily weight } \\
\hline Preweaning & $\mathrm{Y}=63.94 \mathrm{x}+371.4$ & 0.156 & $Y=58.16 x+254.7$ & 0.434 & 0.536 \\
\hline Weaning & $Y=-269.0 x+964.2$ & 0.438 & $Y=-185.7 x+714.2$ & 0.62 & 0.544 \\
\hline
\end{tabular}

Note: $\mathrm{R}=$ correlation coefficient, Sign= significance of the slope among the inoculation with the control group. 
Table 5. Physiological performance in calves inoculated with buffalo's rumen bacteria

\begin{tabular}{|c|c|c|c|c|}
\hline \multirow{2}{*}{ Parameter } & \multicolumn{2}{|c|}{ Preweaning } & \multicolumn{2}{|c|}{ Weaning } \\
\hline & Inoculated & Control & Inoculated & Control \\
\hline Calf $(\mathrm{n})$ & 3 & 4 & 3 & 4 \\
\hline \multicolumn{5}{|c|}{ Respiration rate (breaths/min) } \\
\hline Morning & $39.33 \pm 3.91$ & $42.29 \pm 0.81$ & $36.58 \pm 3.66$ & $34.31 \pm 3.05$ \\
\hline Afternoon & $48.17 \pm 4.76$ & $53.83 \pm 6.20$ & $42.25 \pm 1.52$ & $44.00 \pm 3.67$ \\
\hline \multicolumn{5}{|c|}{ Heart rate (beats/min) } \\
\hline Morning & $82.00 \pm 1.17$ & $83.25 \pm 3.07$ & $82.33 \pm 1.91$ & $81.88 \pm 1.13$ \\
\hline Afternoon & $89.61 \pm 1.00$ & $91.00 \pm 3.23$ & $89.50 \pm 0.25$ & $90.75 \pm 1.22$ \\
\hline \multicolumn{5}{|c|}{ Rectal temperature $\left({ }^{\circ} \mathrm{C}\right)$} \\
\hline Morning & $38.94 \pm 0.16^{\mathrm{a}}$ & $39.15 \pm 0.04^{b}$ & $38.78 \pm 0.19$ & $38.73 \pm 0.11$ \\
\hline Afternoon & $39.44 \pm 0.15$ & $39.53 \pm 0.05$ & $39.22 \pm 0.19$ & $39.20 \pm 0.13$ \\
\hline
\end{tabular}

Note: Means in the same row with different superscripts differ significantly $(\mathrm{P}<0.05)$.

Table 6. Blood profile in calves inoculated with buffalo's rumen bacteria

\begin{tabular}{|c|c|c|c|c|}
\hline \multirow{2}{*}{ Parameter } & \multicolumn{2}{|c|}{ Preweaning } & \multicolumn{2}{|c|}{ Weaning } \\
\hline & Inoculated & Control & Inoculated & Control \\
\hline Calf (n) & 3 & 4 & 3 & 4 \\
\hline Erithrocytes (million/ $/ \mathrm{mm}^{3}$ ) & $8.45 \pm 0.88$ & $8.10 \pm 1.89$ & $8.03 \pm 0.47$ & $7.73 \pm 0.97$ \\
\hline Hematocrit (\%) & $31.66 \pm 2.25$ & $29.68 \pm 4.30$ & $30.50 \pm 4.02$ & $29.18 \pm 1.91$ \\
\hline Hemoglobin (g\%) & $10.25 \pm 1.00$ & $9.79 \pm 1.30$ & $10.44 \pm 1.31$ & $9.66 \pm 0.89$ \\
\hline Leukocytes (thousand $/ \mathrm{mm}^{3}$ ) & $5.65 \pm 2.91$ & $5.51 \pm 3.07$ & $9.02 \pm 1.83^{\mathrm{A}}$ & $3.45 \pm 0.98^{\text {B }}$ \\
\hline \multicolumn{5}{|l|}{ Leukocytes differentiation } \\
\hline Neutrophils (\%) & $23.00 \pm 6.92$ & $38.25 \pm 11.95$ & $36.33 \pm 11.59^{a}$ & $16.00 \pm 9.20^{b}$ \\
\hline Lymphocytes (\%) & $72.33 \pm 8.73$ & $57.00 \pm 11.46$ & $59.66 \pm 14.57$ & $78.00 \pm 7.07$ \\
\hline Monocytes (\%) & $3.66 \pm 2.88$ & $4.25 \pm 0.50$ & $2.33 \pm 1.52$ & $2.50 \pm 1.91$ \\
\hline Eosinophils (\%) & $1.00 \pm 0.00$ & $0.50 \pm 0.57$ & $1.66 \pm 2.88$ & $3.50 \pm 3.31$ \\
\hline Neutrophils/Lymphocyte & $0.33 \pm 0.13$ & $0.73 \pm 0.37$ & $0.66 \pm 0.35$ & $0.21 \pm 0.14$ \\
\hline
\end{tabular}

Note: Means in the same row with different small superscripts differs significantly $(\mathrm{P}<0.05)$; means in the same row with different capital superscript differs significantly $(\mathrm{P}<0.01)$.

vading microorganism, such as cells neutrophils, eosinophils and manocyte (Parham, 2009). Increased levels of neutrophils in the treatment indicated that inoculation of BRB increased the ability of the calf in response to foreign substances and pathogens.

\section{Mineral Status}

The absorption of minerals $\mathrm{Ca}, \mathrm{P}, \mathrm{Mg}, \mathrm{Zn}$, and $\mathrm{Co}$ in both groups of calf is presented in Table 7. Absorptions of minerals $\mathrm{Ca}, \mathrm{P}, \mathrm{Mg}, \mathrm{Zn}$, and $\mathrm{Co}$ in the inoculated calves were not different as compared to those of control calves. Absorptions of mineral Ca, $\mathrm{P}$, and Co were more than $83 \%$. The pattern of mineral absorption tended to increase during the weaning period. The high absorption of minerals indicated that mineral needs of the calves were very high during the growth phase. Darmono (2007) states that $\mathrm{Ca}, \mathrm{Mg}, \mathrm{Na}, \mathrm{K}$, and $\mathrm{P}$ are required to synthesize the structure of the body, such as bones and teeth, whereas $\mathrm{Fe}, \mathrm{Cu}, \mathrm{Zn}, \mathrm{Mo}$, and I elements play a role in facilitating the activity of enzyme and hormonal systems. On the weaning period, Co absorption in the inoculated calves was higher $(\mathrm{P}<0.01)$ than control. This indicated that the inoculation of BRB increased the Co uptake which was possible due to the high synthesis of cyanocobalamin in the rumen bacteria of the inoculated calves (Table 3).

The increased uptake of Co was not related to erythrocytes and hemoglobin levels of calve in each treatment group, although erythrocytes and hemoglobin level of inoculated calves were higher than those of control (Table 6). Wang et al. (2007) suggested that Co supplementation by $0.086 \mathrm{mg} \mathrm{Co} / \mathrm{kg} \mathrm{DM}$ significantly increased level of hemoglobin in lamb. Supplementation of $0.05-1.0 \mathrm{~mL} \mathrm{Co} / \mathrm{kg}$ in fresh feed increased vitamin $B_{12}$ in rumen, and it played a role in formation of hemoglobin (Tiffany et al., 2006).

The level of mineral in the plasma is a reflection of the amount of minerals that absorbed through blood vessels and its value depends on the mineral content in the feed and the rate of absorption (Girindra, 1988). The results showed that the concentrations of $\mathrm{P}$ and $\mathrm{Mg}$ in the blood were in the normal range, but the levels of $\mathrm{Ca}$ during weaning period in both of groups were below the normal range whereas the percentage of uptake was above $94 \%$. This suggested that Ca was needed highly during the weaning period and the Ca content of the ration was lower than that required by the calf. Plasma mineral levels were not different significantly between the two groups. This showed that the inoculation of 
Table 7. Absorption and mineral status in calves inoculated with buffalo's rumen bacteria

\begin{tabular}{|c|c|c|c|c|}
\hline \multirow{2}{*}{ Parameter } & \multicolumn{2}{|c|}{ Preweaning } & \multicolumn{2}{|c|}{ Weaning } \\
\hline & Inoculated & Control & Inoculated & Control \\
\hline Calf (n) & 3 & 4 & 3 & 4 \\
\hline \multicolumn{5}{|l|}{ Absorption } \\
\hline $\mathrm{Ca}(\mathrm{g} / \mathrm{d})$ & $11.31 \pm 2.30$ & $8.60 \pm 3.51$ & $48.40 \pm 1.82$ & $46.49 \pm 1.04$ \\
\hline$P(g / d)$ & $2.03 \pm 0.37$ & $1.57 \pm 0.54$ & $4.19 \pm 0.07^{\mathrm{a}}$ & $4.00 \pm 0.08^{b}$ \\
\hline $\operatorname{Mg}(g / d)$ & $1.43 \pm 0.36$ & $1.05 \pm 0.35$ & $2.10 \pm 0.14$ & $2.26 \pm 0.42$ \\
\hline $\mathrm{Zn}(\mathrm{mg} / \mathrm{d})$ & $46.48 \pm 17.76$ & $32.67 \pm 10.92$ & $124.32 \pm 2.09$ & $121.99 \pm 2.38$ \\
\hline $\mathrm{Co}(\mathrm{mg} / \mathrm{d})$ & $2.00 \pm 0.28$ & $1.55 \pm 0.53$ & $2.86 \pm 0.03^{\mathrm{A}}$ & $2.78 \pm 0.02^{\mathrm{B}}$ \\
\hline \multicolumn{5}{|l|}{ Absorption (\%) } \\
\hline $\mathrm{Ca}$ & $86.40 \pm 6.29$ & $83.96 \pm 12.37$ & $95.95 \pm 3.48$ & $94.64 \pm 1.66$ \\
\hline $\mathrm{P}$ & $84.85 \pm 5.21$ & $86.07 \pm 2.49$ & $90.53 \pm 2.46$ & $89.18 \pm 1.94$ \\
\hline $\mathrm{Mg}$ & $59.47 \pm 7.11$ & $57.44 \pm 5.69$ & $59.12 \pm 3.24$ & $62.42 \pm 6.24$ \\
\hline $\mathrm{Zn}$ & $62.89 \pm 17.50$ & $59.66 \pm 10.71$ & $91.98 \pm 1.03$ & $93.12 \pm 1.69$ \\
\hline Co & $98.16 \pm 0.55$ & $98.65 \pm 0.42$ & $98.33 \pm 0.16$ & $98.56 \pm 0.20$ \\
\hline \multicolumn{5}{|c|}{ Plasma mineral (mg/100mL) } \\
\hline $\mathrm{Ca}$ & $10.20 \pm 1.60$ & $9.41 \pm 0.31$ & $7.21 \pm 0.94$ & $7.59 \pm 1.55$ \\
\hline$P$ & $8.29 \pm 1.24$ & $8.74 \pm 0.70$ & $9.34 \pm 1.81$ & $7.04 \pm 0.90$ \\
\hline $\mathrm{Mg}$ & $3.61 \pm 0.30$ & $3.74 \pm 0.34$ & $3.26 \pm 0.38$ & $3.20 \pm 0.14$ \\
\hline $\mathrm{Zn}$ & $0.73 \pm 0.11$ & $0.68 \pm 0.08$ & $0.49 \pm 0.06$ & $0.54 \pm 0.07$ \\
\hline Co (ppm) & $0.107 \pm 0.030$ & $0.119 \pm 0.039$ & $0.144 \pm 0.041$ & $0.137 \pm 0.023$ \\
\hline
\end{tabular}

Note: Means in the same row with different small superscripts differs significantly $(\mathrm{P}<0.05)$; means in the same row with different capital superscript differs significantly $(\mathrm{P}<0.01)$.

bacteria did not interfere with minerals level of blood and the calves were well utilized the mineral feed. The normal levels of $\mathrm{P}, \mathrm{Mg}$, and $\mathrm{Ca}$ in the blood of dairy cattle were 3.7-10.1, 1.7-4.3, and 3.7-12.0 mg/100 mL, respectively (Krause et al., 1968).

\section{CONCLUSION}

Inoculation of buffalo rumen bacteria into Frisian Holstein calves was effective to increase feed intake, characteristics of leukocytes and neutrophils, and Co uptake during the weaning period. Inoculation of rumen bacteria improves rumen $\mathrm{pH}$ during preweaning and weaning periods. Inoculation of rumen bacteria has no negative effects on digestibility, feed conversion (FCR), average daily gain (ADG), and physiological status of calves.

\section{ACKNOWLEDGEMENT}

This research was supported by the Kerjasama Kemitraan Penelitian Pertanian dengan Perguruan Tinggi (KKP3T), No: 717/LB.620/I.1/3/2008.

\section{REFERENCES}

Asmare, B. 2014. Biotechnological advances for animal nutrition and feed improvement. World J. Agric. Res 3:115-118. http://dx.doi.org/10.12691/wjar-2-3-5

Anandan, S., A. Dey, S. M. Deb, S. Kumar, \& P. C. Harbola. 1999. Effect of curds as probiotic supplement on performance of Cheghu crossbred kids. Small Rumin. Res. 32:9396. http://dx.doi.org/10.1016/S0921-4488(98)00159-X

[AOAC] Association of Official Analytical Chemist. 1990. Methods of Analysis of the Association of Analytical
Chemist. $16^{\text {th }}$ Ed. Assoc. Off. Anal. Chem., Arlington.

Campbell, C. M. \& L. James. 2009. Atomic absorption spectrophotometric and ethylenediaminetetraacetate-tritation methods for calcium and magnesium determinations. J. Dairy Sci. 52: 121-124.

Castells, L. A. Bach, A. Aris, \& M. Terre. 2013. Effects of forages provision forr young calves on rumen fermentation and development of the gastrointestinal tract. J. Dairy Sci. 96:5226-5236. http://dx.doi.org/10.3168/jds.2012-6419

Conway, E. J. 1950. Microdiffusion. Analysis and Volumetric Error. ( $\left.2^{\text {nd }} E d.\right)$. Crosby Lockwood and Son, London.

Darmono. 2007. Penyakit defisiensi mineral pada ternak ruminansia dan upaya pencegahannya. J. Litbang Pertanian. 26: 391-404.

Davis, C. L. \& J. K. Drackley. 1998. The Development, Nutrition, and Management of the Young Calf. Lowa State Press. Lowa.

Desnoyers, M., S. Giger-Reverdin, G. Bertin, C. Duvaux-Ponter, \& D. Sauvant. 2009. Meta-analysis of the influence of Saccharomyces cerevisiae supplementation on ruminal parameters and milk production of ruminants. J. Dairy Sci. 92:1620-1632. http://dx.doi.org/10.3168/jds.2008-1414

Dezfouli, M. R. M., P. Tajik, M. Bolourchi, \& H. Mahmoudzadeh. 2007. Effects of probiotics suplementation in daily milk intake of new born calves on body weight gain, body height, diarrhea occurrence and health condition. Pak J. Bio. Sci. 10: 3136-3140.

Dias, R. S., H. O. Patino, S. Lopez, E. Piates, K. C., Swanson, \& J. France. 2011. Relatinship between chewing behavior, digestibility, and digesta passage kinetics in strer feed oat hay at restricted and ad libitum intake. J Anim. Sci. 89:18731880. http://dx.doi.org/10.2527/jas.2010-3156

Frizzo, L. S., L. P. Soto, M. V. Zbrun, E. Bertozzi, G. Sequiera, R. Rodriquez Aimesto, \& M. R. Rosmini. 2010. Lactic acid bacteria to improve growth performance in young calves fed milk replacer and spry-dried whey powder. J. Anim. Feed. Sci. Tech. 157:159-167. http://dx.doi.org/10.1016/ j.anifeedsci.2010.03.005 
Girindra, A. 1988. Biokimia Patologi Hewan. Pusat Antar Universitas. Institut Pertanian Bogor, Bogor.

Goldman, E. \& L. H. Green. 2008. Practice Handbook of Microbiology. $2^{\text {nd }}$ Ed. CRC Press. United Kingdom.

Jezek, J., N. Marija, S. Joze, \& K. Martina. 2011. Age related changes and reference intervals of haematological variables in dairy calves. Bull. Vet. Inst. Pulawy 55:471-478

Khalid, M. F., M. A. Shahzad, M. Sarwar, A. U. Rehman, M. Sharif, \& N. Mukhtar. 2011. Probiotics and lamb performance: A review. Afr. J. Agric. Res. 6: 5198-5203.

Kinal, S., A. Korniewicz, A. Rzasa, D. Korniewicz, K. Bialon, \& B. Lubojemska. 2007. Effect of Saccharomyces cerevisiae yeast on metabolites on colostrums quality and passive immunity transfer in calves. Bull. Vet. Inst. Pulaway 51:105-108

Krause, G. F., A. G. Lane, \& J. R. Campbell. 1968. Blood mineral composition of ruminant. J. Anim. Sci. 27 : 766-770

Kumar, B. \& S. K. Sirohi. 2013. Effect of issolate of ruminal fibrolytic bacterial structure supplementaion on fibrolytic bacterial population and survivability of inoculate bacterial strain in lactating Murrah buffalos. Vet World 6:14-17. http://dx.doi.org/10.5455/vetworld.2013.14-17

Lee, Y. K. \& S. Salminen. 2009. Handbook of Probiotics and Prebiotics. $2^{\text {nd }}$ Ed. John \& Wiley Inc., New Jersey.

Lehmann, J. \& A. Enders. 2012. Comparison of wet-digestion and dry-ashing methods for total elemental analysis of biochar. Communications in Soil Sci. Plant Anal. 43:10421052. http://dx.doi.org/10.1080/00103624.2012.656167

Lichtman, M. A., E. Beutler, T. J. Kipps, U. Seligsohn, K. Kaushansky, \& J. T. Prchal. 2006. William Hematology $\left(7^{\text {th }}\right.$ Ed). McGraw-Hill. New York.

Musa, H. H., S. L. We, C. H. Zhu, H. I. Seri, \& G. Q. Zhu. 2009. The potential benefits of probiotics in animal production and health. J. Anim. Vet. Adv. 8: 313-321.

McCowen, K. C. \& B. R. Bistrian. 2003. Immunonutrition: problematic or problem solving?. Am J Clin Nutr. 77:764-770.

Pandya, P. R., K. M. Singh, S. Parnerkar, A. K. Tripathi, H. H. Mehta, D. N. Rank, R. K. Kothari, \& C. G. Joshi. 2010. Bacterial diversity in the rumen of Indian Surti buffalo (Bubalus bubalis, assessed by $16 \mathrm{~S}$ rDNA analysis. J. Appl. Genet. 51:395-402. http://dx.doi.org/10.1007/BF03208869

Parham, P. 2009. The Immune System ( $3^{\text {rd }}$ Ed). Taylor \& Francis Group. United Kingdom.

Prihantoro, I., T. Toharmat, D. Evvyernie, Suryani, \& L. Abdullah. 2012. Kemampuan isolat bakteri pencerna serat asal rumen kerbau pada berbagai sumber hijauan pakan. JITV 17: $189-200$

Prihantoro, I., D. Evvyernie, Suryani, L. Abdullah, N.S. Yunitasari, A. P. Sari, D. Khairunisa, A. Haziq, N. Rahayu, \& T. Toharmat. 2012. Potensi bakteri pencerna serat asal rumen kerbau yang diinokulasi pada pedet Frisian Holstein selama periode prasapih. JITV 17:297-304.
Salahudin, H., H. Akhter, M. A. Miah, \& N. Ahmad. 2013. Effect of probiotics on haematology and biochemical parameters in mice. The Bangladesh Vet. 30:20-24.

Sawanon, S. \& Y. Kobayashi. 2006. Synergistic fibrolysis in the rumen by cellulolytic Ruminococcus flavefaciens and noncellulolytic Selenomonas ruminantium: Evidence in defined cultures. Anim. Sci. J. 77:208-214. http://dx.doi.org/10.1111/ j.1740-0929.2006.00339.x

Shinkai, T. \& Y. Kobayashi. 2007. Localization of ruminal cellulolytic bacteria on plant fibrous materials as determined by fluorescence in situ hybridization and real-time PCR. J. Appl. Environ. Microbiol. 73:1646-1652. http://dx.doi. org/10.1128/AEM.01896-06

Smith, J. B. \& Mangkoewidjojo. 1988. Pemeliharaan, Pembiakan dan Penggunaan Hewan Percobaan di Daerah Tropis. UI Press, Jakarta.

Suarez, B. J., C. G. Van Reenen, W. J. J. Gerrits, N. Stockhove, A. M. Van Vuuren, \& J. Dijkstra. 2006. Effects of supplementing concentrates differing in carbohydrate composition to veal calf diets: II. Rumen development. J. Dairy Sci. 89: 4376-4386

Swinney-Floyd, D., B. A. Gardner, F. N. Owens, T. Rehberger, \& T. Parrott. 1999. Effect of inoculation with either strain P-63 alone or in combination with Lactobacillus acidophilus LA53545 on performance of feedlot cattle. J. Anim. Sci. 77:77. (Abstr.)

Tiffany, M. E., V. Felner, \& J. W. Spears. 2006. Influence of Cobalt concentration on vitamin $B_{12}$ production and fermentation of mixed ruminal micro-organism grown in continous culture flow-trough fermentors. J. Anim. Sci. 84:635-640.

Ulvshammar, K. 2014. Effect of shade on milk production in Swedish dairy cows on pasture. Master thesis. Swedish University of Agriculture Sciences.

Wahyudi, A., L. Hendraningsih, \& A. Malik. 2010. Potency of fibrolytic bacteria isolated from Indonesian sheep's colon as inoculum for biogas and methane production. Afr. J. Biotechnol. 9: 2994-2999.

Wallace, R. J. \& C. J. Newbold. 1993. Rumen fermentation and its manipulation: The development of yeast culture as feed additives. In: T. P. Lyons (ed.). Biotechnology in the Feed Industry, Alltech Technical Publications, Kentucky. pp. 173-192.

Wang, R. L., W. Zhang, X. P. Zhu, L. L. Yu, \& Z. H. Jia. 2007. Effect of cobalt and copper supplementation on vitamin $\mathrm{B}_{12}$ status and blood parameters in lambs. J. Anim. Feed Sci. 16:471-476.

Yaqub, S., J. G. Anderson, S. J. Macregor, \& N. J. Rowan. 2004. Use of a flouescent viability stain to assess lethal and sublethal injury in food-borne bacteriaexposed to high intensy pulsed electric field. Lett. Appl. Microbiol. 39:246-251. http://dx.doi.org/10.1111/j.1472-765X.2004.01571.x 